\title{
Natural Suppression of Rhizoctonia Bare Patch in a Long-Term No-Till Cropping Systems Experiment
}

W. F. Schillinger, Department of Crop and Soil Sciences, Washington State University, Dryland Research Station, Lind 99341; and T. C. Paulitz, Root Disease and Biological Control Unit, United States Department of Agriculture-Agricultural Research Service, Pullman, WA 99164

\begin{abstract}
Schillinger, W. F., and Paulitz, T. C. 2014. Natural suppression of Rhizoctonia bare patch in a long-term no-till cropping systems experiment. Plant Dis. 98:389-394.

The soilborne fungus Rhizoctonia solani AG-8 is a major concern for farmers who practice no-till in the inland Pacific Northwest of the United States. Bare patches caused by Rhizoctonia spp. first appeared in 1999 during year 3 of a 15-year no-till cropping systems experiment near Ritzville, WA (269 $\mathrm{mm}$ of annual precipitation). The extent and pattern of patches were mapped each year from 1999 to 2012 at the 8ha study site with a backpack-mounted global positioning system equipped with mapping software. Bare patches appeared in winter and spring wheat (SW; Triticum aestivum), spring barley (SB; Hordeum vulgare), yellow mustard (Brassica hirta), and safflower (Carthamus tinctorius). At its peak in years 5 to 7 , bare patches occupied as much as $18 \%$ of total plot area in continuous annual monoculture SW. The

levels by year 11 . No measurable patches were present in years 12 to 15. Patch area was significantly greater in continuous SW compared with SW grown in a 2-year rotation with SB. Additionally, the 15-year average grain yield for SW in rotation with SB was significantly greater than for continuous SW. Russian thistle (Salsola tragus), a troublesome broadleaf weed with a fast-growing tap root, was the only plant that grew within patches. This article reports the first direct evidence of natural suppression of Rhizoctonia bare patch with long-term no-till in North America. This suppression also developed in a rotation that contained broadleaf crops (yellow mustard and safflower) in all but 5 years of the study, and the suppression was maintained when safflower was added back to the rotation.
\end{abstract} area of bare patches began to decline in year 8 and reached near zero
Rhizoctonia bare patch and root rot is a yield-limiting disease in dryland wheat production areas around the world. It is widely distributed throughout the wheat-cropping zones (15) and is especially prevalent in the low-precipitation ( $<300 \mathrm{~mm}$ annual) dryland cropping region of eastern Washington (23). Caused by Rhizoctonia solani AG-8, it was first reported in the U.S. Pacific Northwest (PNW) in the mid 1980s $(27,40)$, although it had been studied in Australia since the 1930s (15). In its most acute phase, the disease causes patches of severely stunted wheat throughout the field. The pathogen attacks the seminal and crown roots of seedlings, producing characteristic spear tipping and cortical rot and killing the lateral roots, with stunted seedlings not yielding any marketable grain $(24,34)$. In severe situations, these patches can cover 15 to $20 \%$ of the field (6).

Rhizoctonia bare patch is exacerbated by reduction in tillage found in no-till or direct-seed systems $(27,33,40)$. In the first few years during conversion from tillage to no-till, the disease can become very severe $(6,33)$ but will decline with time (32). In areas with higher precipitation ( $>340 \mathrm{~mm}$ annually) in the PNW, the pathogen does not cause patches but still causes root rot and uneven height of plants. At present, there is no resistance or tolerance in adapted cultivars (38) and no chemical control, other than seed treatment, which provides limited protection to young seedlings (22) but often no yield increase (37). Crop rotation has also not been effective because of the wide host range of the pathogen,

Corresponding author: W. F. Schillinger,

E-mail: william.schillinger@wsu.edu

* The $\boldsymbol{e}$-Xtra logo stands for "electronic extra" and indicates that Figures 1 and 5 appear in color in the online edition.

Accepted for publication 27 September 2013.

http://dx.doi.org/10.1094/PDIS-04-13-0420-RE

(C) 2014 The American Phytopathological Society which includes both cereals and broadleaf rotation crops such as pea (Pisum sativum L.), chickpea (Cicer arietinum L.), lentil (Lens culinaris Medik.), mustard, and canola (Brassica napus L.) $(6,34)$. This disease is managed primarily by cultural techniques, such as controlling weeds and volunteers to prevent green-bridge carryover of inoculum to the new crop (19). Glyphosate application is a standard method to reduce weed pressure. Applications are timed to kill volunteers and weeds 2 to 3 weeks before the crop is planted, thus reducing the fungal carryover and increased disease that can occur with applications closer to planting (1).

Soilborne pathogens can be suppressed by the development of antagonistic microbial communities in the soil. Such suppression is often associated with monocropping, and is sometimes called "monocropping decline". This phenomenon of natural suppression was most widely documented in the case of take-all caused by Gaeumannomyces graminis var. tritici. During the first few years of continuous wheat, disease increases, then starts to decline after year 4 or 5 and, eventually, declines to a baseline level, despite the fact that the pathogen is still present and the host is susceptible $(5,41)$. The suppression is due to microbes, in this case Pseudomonas spp., that produce antifungal metabolites such as phloroglucinol and phenazine $(11,41)$.

Rhizoctonia decline has been described in Australia for continuous cropping of wheat under no-till conditions $(14,28)$. Like takeall decline, the disease increased when tillage was stopped but then declined after 7 to 9 years. Research on this subject has continued in Australia $(3,9)$ but the mechanisms behind this are not well known. However, there is some experimental and anecdotal evidence that Rhizoctonia decline may be present in the PNW. Soil from patches or highly infected areas can be brought into the greenhouse and continually cropped with wheat or barley. After a few crop cycles, the disease significantly declines $(13,20)$. Disease increases 2 to 4 years after tillage is stopped $(6,27)$ in surveys comparing long-term no-till farms ( $>12$ years) with adjacent conventional tillage farms, there was no difference in Rhizoctonia disease (32). In a long-term cropping systems experiment near Ritzville, WA, the focus of this article, Rhizoctonia bare patches 
covered less land area in spring wheat (SW) grown in a 2-year rotation with spring barley (SB) compared with continuous SW (31), even though barley is more susceptible than wheat to $R$. solani AG-8.

The overall objective of our long-term study was to evaluate the agronomic and economic feasibility of alternative no-till cropping systems in the typical winter wheat (WW)-summer fallow production region in eastern Washington (30). Beginning in year 3 of the experiment, severe Rhizoctonia bare patch occurred across all crops in all the rotations $(6,30)$. This article documents the (i) increase and then decline in patch area, (ii) enhanced grain yield of SW when grown in rotation with SB compared with continuous annual SW, and (iii) soil water dynamics in a 2-year SW-SB rotation compared with continuous annual SW during a 15-year time period, as well as (iv) ability of Russian thistle to flourish in bare patches where no other plant would grow. We report here the first direct evidence of natural suppression of Rhizoctonia bare patch decline in the field in North America and the first in the world literature to document suppression with multiple crops (i.e., other than monoculture wheat).

\section{Materials and Methods}

Overview. A long-term field study of no-till annual cropping systems was initiated in March 1997 at the Ronald Jirava farm near Ritzville, WA. Several crop species and rotation sequences were evaluated during different phases of the large-scale experiment (30). This article is focused on (i) continuous annual SW versus a 2-year SW-SB rotation that have been present since the inception of the experiment and (ii) a diversified cropping system which included the broadleaf crops safflower (SAF) and yellow mustard (YM). As previously described (30), SAF and YM were rotated with SW, SB, and WW from 1997 to 2004. Due to poor agronomic and economic performance of SAF and YM (30), oilseed crops were discontinued in 2005, where the rotation then reverted to small-grain cereals. Beginning in 2010, SAF was reintroduced into the experiment. Specific rotation sequences in the oilseed rotations were as follows: phase 1, 1997 to 2000: SAF-YM-SW-SW; phase 2, 2001 to 2004: WW-SB-YM-SW; phase 3, 2005 to 2010: no-till fallow-WW-SB-SW; and phase 4, 2010 to present: tilled fallowWW-SAF.

Continuous annual SW was planted on the same plots of land every year whereas, in the 2-year rotation, SW and SB were rotated, with both phases of the rotation present each year. All phases of the 4-year (1997 to 2009) and 3-year (2010 to present) oilseedbased rotations were also present each year. Although tilled fallow was introduced into the oilseed rotation in phase 4 (i.e., beginning in 2010), the 2010 and 2011 SAF crops were grown on plots that had not been tilled because the temporal entry of SAF after the soil had been tilled during fallow did not begin until 2012. Thus, all data reported in this article are from plots that had not been tilled since the inception of the experiment. Experimental design was a randomized complete block with four replications. Individual plot size was 9 by $150 \mathrm{~m}$. The field where the experiment was conducted had been in a tillage-based WW-summer fallow rotation for more than 100 years prior to the beginning of the study. The soil at the experiment site is a Ritzville silt loam (coarse-silty, mixed, superactive, mesic Calcidic Haploxerolls). Soil is more than $2 \mathrm{~m}$ deep, with no rocks or restrictive layers, and slope is less than $1 \%$.

Precipitation was measured on site during all years of the study with a computerized weather station. Two-thirds of precipitation in the PNW generally occurs from October to March, with one-third as snow. One-fourth of annual precipitation occurs during April to June, with July to September as the driest months. Although the experiment was initiated in 1997, only data from 1998 and onward are reported here to allow for temporal entry of SB and its effects on SW production (i.e., all crops were planted into wheat stubble in 1997).

Field operations. In March of each year, glyphosate (N-(phosphonomethyl) glycine) herbicide was applied 2 to 4 weeks before planting spring crops at rates of 0.43 to $0.60 \mathrm{~kg}$ acid equivalent $\mathrm{ha}^{-1}$ to control weeds and limit the buildup of fungal inoculum on living hosts between harvest and planting (1). SW and SB were planted within a 2-day period during the last week in March or first week of April each year.

All plots were planted and fertilized in one-pass with a no-till drill directly into the undisturbed soil and stubble left from the previous crop. During the first 3 years (1997 to 1999), we used the cooperating farmer's Flexi-Coil 6000 air-delivery no-till drill (CNH America LLC) equipped with Barton II dual-disk openers on 19 -cm row spacing. From 2000 to 2005, a custom-built no-till drill equipped with Cross-slot notched-coulter openers (Cross Slot No Tillage Drills) on $20-\mathrm{cm}$ row spacing was used. From 2006 onwards, we used a Kile hoe-type-opener no-till drill (Ron Kile) that placed seed in paired rows $10 \mathrm{~cm}$ apart with $30-\mathrm{cm}$ spacing between openers. All three no-till drills used during the course of the experiment provided simultaneous and precision placement of seed and liquid fertilizer, with the fertilizer placed beneath and slightly to one side of the seed (Flexi-Coil 6000 and Cross-slot drills) or beneath and between the paired rows (Kile drill).

Seeding rate for $\mathrm{SW}$ and $\mathrm{SB}$ over the years was held constant at $78 \mathrm{~kg} \mathrm{ha}^{-1}$. Solution $32\left(\mathrm{NH}_{4} \mathrm{NO}_{3}+\right.$ urea $)$ provided the base for liquid fertilizer to supply an average of $\mathrm{N}$ at $38 \mathrm{~kg} \mathrm{ha}^{-1}, \mathrm{P}$ (aqueous solution of $\mathrm{NH}_{4} \mathrm{H}_{2} \mathrm{PO}_{4}$ ) at $7 \mathrm{~kg} \mathrm{ha}^{-1}$, and $\mathrm{S}$ (aqueous solution of $\left.\left(\mathrm{NH}_{4}\right)_{2} \mathrm{~S}_{2} \mathrm{O}_{3}\right)$ at $10 \mathrm{~kg} \mathrm{ha}^{-1}$. Fertilizer needs based on a yield goal were determined by preplant available soil water and soil test for residual N, P, and S. The cultivars used from 1997 to 2009 were 'Alpowa' SW and 'Baronesse' SB. Beginning in 2010, the cultivars were changed to 'Louise' SW and 'Bob' SB to reflect the higher grain yield potential of these new cultivars.

Between the tillering and jointing stages of plant development for SW and SB (12), labeled rates of varied wide-spectrum broadleaf herbicide formulations were applied for in-crop broadleaf weed control. Herbicides used were 2,4-D ester, dimethylamine salt of dicamba, bromoxynil, thifensulfuron + tribenuron, and bromoxynil + pyrasulfototle. Weeds were identified as they occurred, taking note of whether they grew in bare patches or surrounding healthy crop areas. Russian thistle, a major broadleaf weed of spring-planted crops (4), was present at time of grain harvest in early August in 9 of 15 years. When present, Russian thistle was controlled 7 to 10 days after grain harvest with an application of paraquat (gramoxene inteon) or glyphosate herbicide. Further details on cultural practices and inputs used in the experiment are found in Schillinger et al. (30).

Soil water. Water content in a $1.8-\mathrm{m}$ soil profile was measured in all plots in late March to early April and again just after grain harvest in early August. Soil water measurements were obtained in uniform stubble at least $2 \mathrm{~m}$ in distance from the outer edge of any bare patch. Soil volumetric water content in the $0-$ to $30-\mathrm{cm}$ depth was determined from two $15-\mathrm{cm}$-deep core samples using gravimetric procedures described by Topp and Ferre (39) and in the 30to $180-\mathrm{cm}$ depth in $15-\mathrm{cm}$ increments by neutron attenuation (10).

Measurement of Rhizoctonia bare patch area. We define a Rhizoctonia bare patch as a contiguous circle or elliptical-shaped area where the crop is severely stunted or dead (Fig. 1). The location, size, and total land area covered by patches were determined during the first half of June with a Pathfinder Pro XR global positioning system (GPS) (Timble Navigation) equipped with mapping software. Measurements were obtained by circling each clearly visible Rhizoctonia patch with the backpack-mounted GPS mapping unit. Rhizoctonia bare patch areas were mapped every year from 1999 to 2012, except in 2001, when severe drought made it difficult to discern the border areas between Rhizoctonia bare patches and water-stressed crops. These patches were shown to be caused by $R$. solani AG-8, based on isolations from soil (21), and quantification of DNA using the Predicta-B (South Australia Research and Development Institute) (17).

Plant stand establishment and grain yield. Plant stand establishment of SW and SB was determined by counting individual plants in a $1-\mathrm{m}^{2}$ area 21 days after planting. Measurements were obtained from three areas in each plot and the numbers then aver- 
aged. Grain yield was determined in early August using a commercial-sized combine to harvest a 6.1-by-150-m area in each plot and then weighing the grain in a weigh wagon. The combine was equipped with a chaff spreader and straw chopper to evenly distribute chaff and straw along the width of the combine cutting platform.

Statistical procedures. Analysis of variance (ANOVA) was conducted for soil water content, plant stand establishment, Rhizoctonia bare patch area, and grain yield for individual years and combined over the 15 years. Tukey's honest significant difference test was used in conjunction with the ANOVA using Statistix 10 software (Analytical Software) to determine means that were significantly different from each other. All ANOVA tests were done at the $5 \%$ level of significance.

\section{Results}

Bare patch area. Patches first appeared in 1999, in year 3 of the experiment. During its peak (years 5 to 7), bare patches occupied as much as $18 \%$ of total plot area in continuous SW (Fig. 2). Continuous SW had significantly $(P<0.05)$ greater patch area than SW after SB in every year it was measured from years 3 to 9 (1999 to 2005) (Fig. 2). The area of bare patches began to noticeably decline in year 8 and reached near-zero levels by year 11 (2008; Fig. 2). Bare patch was active at typical levels in commercial notill annually cropped wheat fields in higher-precipitation cropping zones southeast of Ritzville in those years. Although some residual areas were visible where the crop was somewhat stunted, essen-
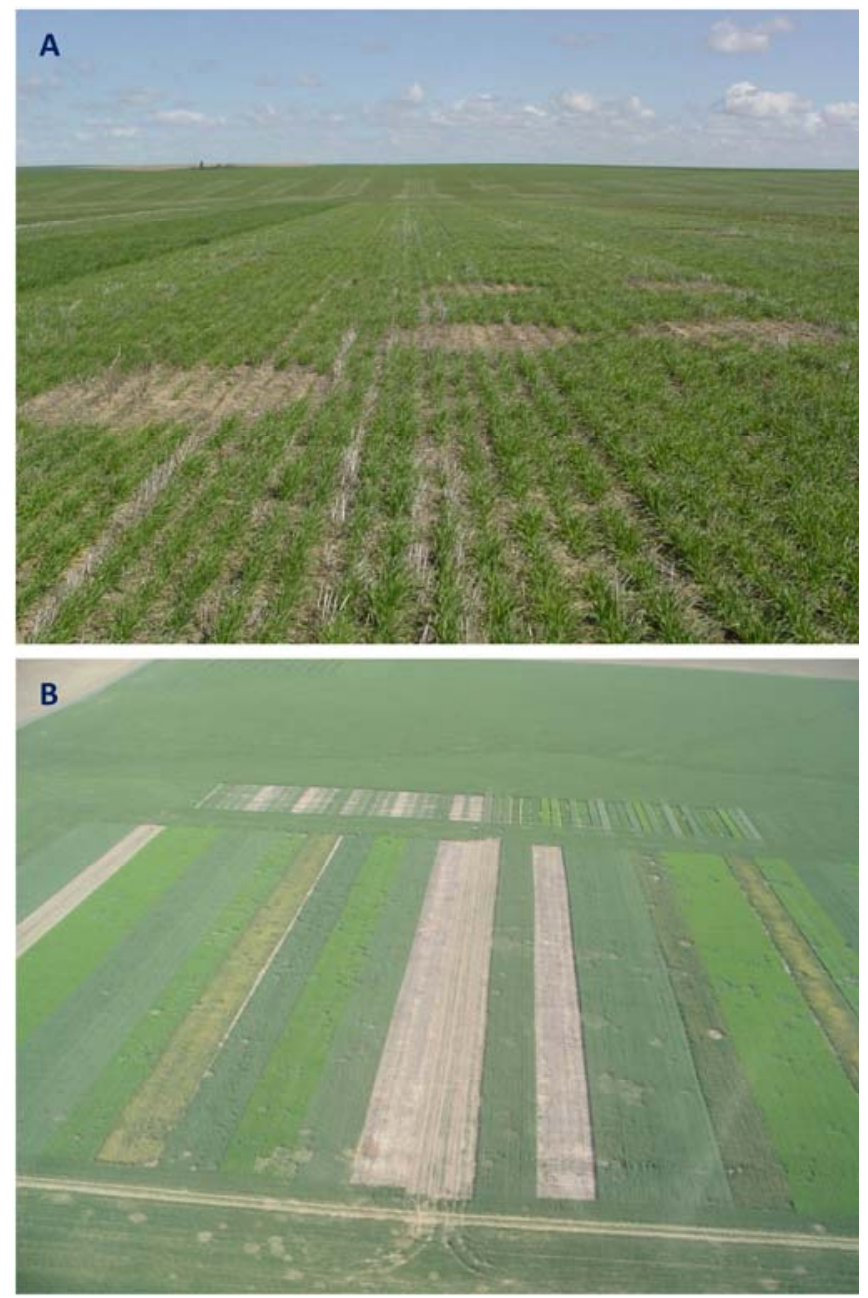

Fig. 1. Bare patches caused by Rhizoctonia solani AG-8 in a long-term no-till cropping systems experiment near Ritzville, WA. A, Spring barley (left) and spring wheat (right) during juvenile growth period in early May 2003. B, Aerial overview of one replicate of the large-scale experiment in early July 2006. Bare patch was in decline by 2006 . tially no measureable bare patch areas were present from years 12 to 15 . Over the 14 years from 1999 to 2012 , patches averaged $5.7 \%$ of total plot area in continuous SW versus $2.9 \%$ for SW after SB, these differences being highly statistically significant $(P<0.001$; Fig. 2). The average bare patch area for the years 3 to 11 (i.e., the time period when quantifiable patches could be measured) was $9.1 \%$ for continuous SW and $4.6 \%$ for SW after SB. Rhizoctonia spp. also were present in SB (in the SW-SB rotation). with bare patch averaging $8.5 \%$ of total area from years 3 through 11 (yearly data not shown).

Bare patch in the oilseed rotation also first appeared in 1999 (30), although mapping for bare patch in SAF and YM did not begin until 2000. Bare patch area in SAF was $7.3 \%$ in 2000. Bare patch area in YM was $11.1,18.1$, and $14.6 \%$ in 2000, 2003, and 2004, respectively. YM was planted twice and killed both times by frost in 2002 and these plots were thereafter left fallow for the 2002 crop year; thus, bare patches were not present. The $18.1 \%$ bare patch area in YM in 2003 was significantly greater than that of WW, SW, and SB in the same rotation. Details on bare patch area and grain yield of all crops in the 4-year oilseed rotation as well as that for all rotations in the entire experiment from 1997 to 2004 are found in Schillinger et al. (30).

When the 4-year oilseed rotation reverted to a 4-year cerealsonly rotation of no-till fallow-WW-SB-SW in 2005, percent patch area followed the same decline pattern of continuous SW and SW after SB as shown in Figure 2. Patch area for WW was 3.0, 2.7, 0, and $0 \%$ from 2006 to 2009 (note: plots going into WW in 2006 were left fallow in 2005). For SW, patch area was 8.3, 3.2, 1.2, 0 , and $0 \%$, respectively for 2005 to 2009 . Similarly, patch area in SB was $10.1,9.5,6.2,0$, and $0 \%$, respectively for the years 2005 to 2009.

Since SAF was reintroduced to these same plots in 2010, there has been no measureable bare patch area. There has been no measureable bare patch area in any of the several crop-rotation treatments (total $=56$ plots) in the entire experiment since 2008 .

SW grain yield. Crop-year (1 September to 31 August) precipitation during the study period ranged from 154 to $356 \mathrm{~mm}$ and averaged $269 \mathrm{~mm}$ (Fig. 3). SW grain yields following SB were generally greater than in continuous SW, although within-year yield differences were only significantly different in 2 of 15 years (Fig. 3). However, when averaged over the 15-year period, there were highly significant differences in grain yield between the two treatments: 1,900 versus $1,994 \mathrm{~kg} /$ ha for continuous $\mathrm{SW}$ and $\mathrm{SW}$ after SB, respectively (Fig 3). SB grain yields in the SW-SB rotation averaged $1,902 \mathrm{~kg} / \mathrm{ha}$ over the 15 -year period (data not shown).

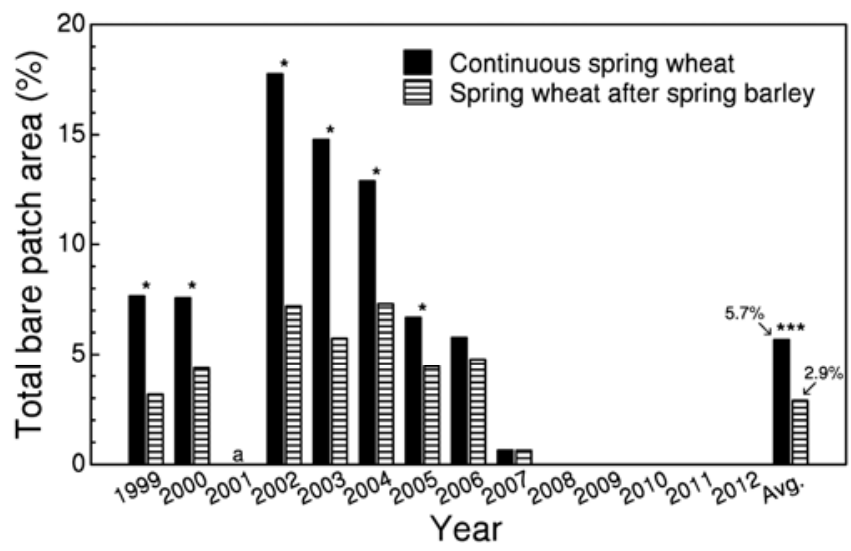

Fig. 2. Total bare patch area caused by Rhizoctonia solani AG-8 was significantly greater during years 3 to 9 (1999 to 2005) in continuous annual spring wheat (SW) compared with SW grown in a 2-year rotation with spring barley. Crops were grown no-till in all years. Bare patch area began to slowly decline in 2003 and, by 2008 and thereafter, was nearly totally suppressed. Patch area was not measured in 2001 due to severe drought which made it difficult to discern bare patches from water-stressed crops; ${ }^{*}$ and ${ }^{* * *}$ indicate significantly different at $P<0.05$ and 0.001 , respectively. 


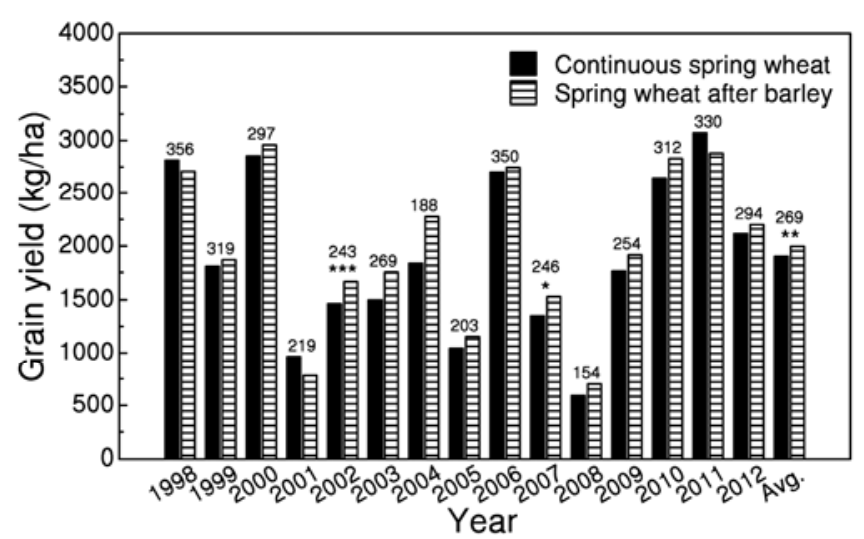

Fig. 3. Grain yield of continuous annual spring wheat (SW) compared with SW grown in a 2-year SW-spring barley rotation, with all crops grown no-till. Within-year grain yield differences between treatments were significantly different only in 2002 and 2007; however, highly significant $(P<0.01)$ differences in grain yield occurred when averaged over the 15 years (1,900 versus $1,994 \mathrm{~kg} / \mathrm{ha})$. Numbers over the bars each year are crop-year (1 September to 31 August) precipitation (in centimeters) as well as the 15 -year average; ${ }^{*},{ }^{* *}$, and ${ }^{* *}$ indicate significantly different at $P<0.05,0.01$, and 0.001 , respectively.

The grain yield advantage of SW after SB was generally present during years of both low and high precipitation. The 2004 crop year was notable for relatively high grain yields despite only 188 $\mathrm{mm}$ of precipitation during the entire year (Fig. 3), this being largely due, in our opinion, to the timely $34 \mathrm{~mm}$ of rain that occurred during May (data not shown) during the stem elongation growth stage.

Soil water. Over the entire 15-year study period there were never any differences in soil water use in continuous SW, SW after SB, or SB after SW either immediately after grain harvest in early August or at time of planting in late March to early April (Fig. 4). The quantity of soil water at time of planting varied from $15 \mathrm{~cm}$ in 2001 to $37 \mathrm{~cm}$ in 2006 but there were never any differences between the two treatments in any year or when averaged over years (Fig. 4).

Russian thistle growth in bare patch areas. During the years of quantifiable bare patch activity (i.e., years 3 to 11 ; 1999 to 2007), the only plant that would grow within bare patches was Russian thistle (Fig. 5). Juvenile Russian thistle had difficulty with establishment within bare patches, showing stunting and root pruning as described earlier. However, beginning in 2003, a year when bare patch area was near its peak (Fig. 2), the tap root of some Russian thistle plants penetrated through the $R$. solani inoculum in the upper layer of the soil and flourished on the "islands" of stranded water within bare patches (Fig. 5). The roots of Russian thistle can extend more than $2 \mathrm{~m}$ deep and $5 \mathrm{~m}$ laterally (4) but the inoculum of $R$. solani is primarily in the top $20 \mathrm{~cm}$ of the soil (20). Other weeds present in the experiment were horse weed (Conyza canadensis L.), prickly lettuce (Lactuca serriola L.), common lamb's quarter (Chenopodium album L.), tumble mustard (Sisymbrium altissimum L.), tansy mustard (Descurainia pinnata L.), and downy brome (Bromus tectorum L.); however, none of these weeds were ever present within bare patches. This held true for all crops in the entire 8-ha no-till cropping experiment area, which included SW, SB, WW, YM, and SAF..

\section{Discussion}

Rhizoctonia bare patch and root rot continue to be a major problem in the dryland wheat-producing areas of the PNW (19) and Australia (15). It is increased under no-till conditions and lack of tillage $(27,33)$. The reasons for this are not known. Tillage may break up the hyphal network (29) or result in an increase of microbial activity that suppresses the pathogen.

In Whitman County, WA, one of the world's highest-yielding rainfed wheat yield production areas, the adoption of no-till by farmers was only $12 \%$ in 2008 (D. Roe, personal communication).

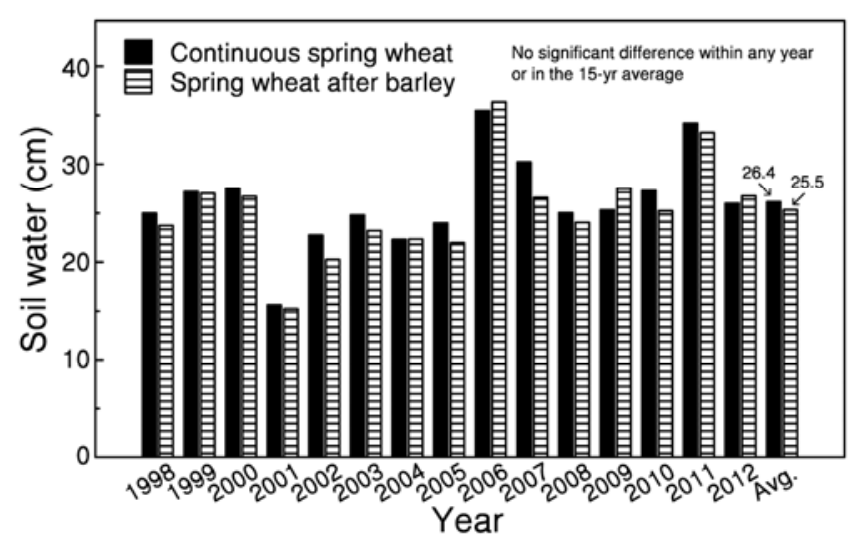

Fig. 4. Soil water content measured in late March to early April, just before planting, in standing and undisturbed stubble of the continuous spring wheat (SW) treatment compared with standing and undisturbed spring barley (SB) stubble in the 2-year SW-SB rotation. There were never any statistically significant differences in soil water content between the two treatments, although the continuous SW treatment had $0.9 \mathrm{~cm}$ more water than after SB in the SW-SB rotation when averaged over the 15 years. Data show that soil water can be eliminated as a factor for SW grain yield differences between the two treatments.

Benefits of no-till include a reduction in fuel consumption by up to $80 \%$ (2) due to the elimination of tillage operations. Organic matter increases with no-till $(7,8,30)$, improving soil quality and structure. However, most importantly, soil erosion from wind and water is significantly reduced. Gradual reductions in tillage from 1982 to 1997 have reduced soil loss from farmland in the United States by an estimated one billion metric tons per year (26).

The current study provides the first documentation of natural suppression of Rhizoctonia bare patch in North America. This suppression also developed in a rotation that contained broadleaf crops (SAF and YM) in 11 of 16 years (i.e., 1997 to 2004 and 2010 to 2012), and the suppression was maintained when SAF was added back to the experiment in 2010. This is in contrast to the classic take-all monoculture decline, where the suppression is broken when a broadleaf crop is introduced into a monoculture wheat rotation (41). This natural decline in Rhizoctonia disease under continuous wheat has only been previously documented in Australia $(14,28)$. One site was in Avon, South Australia and is the focus of intensive research using next-generation sequencing to look at microbial communities (V. V. S. R. Gupta, personal communication). Another site was identified in the 1980s in Esperance, Western Australia (14). The soil of this farm at Esperance was more recently sampled for DNA quantification of the pathogen and disease ratings, and 10 suppressive fields were identified (16). However, when these sites were assessed with a bioassay based on sucrose additions, only five were moderately suppressive. We have also used next-generation pyrosequencing to look at bacterial communities in the bulk soil and rhizosphere of wheat plants grown in active patches, healthy areas, and recovered patches during the last few years of the decline in the continuous annual SW treatment at our Ritzville site $(25,42,43)$. These studies documented the predominance of taxa in the phylum Bacteroidetes (Flavobacterium and Chryseobacterium) and the family Oxalobacteriaceae in the order Burkholderiales in the rhizosphere of diseased plants, which were present in much lower frequencies on healthy plants. Some of these could be potential antagonists that build up to high levels in active patches, inhibit the infection of Rhizoctonia spp. in the rhizosphere, and result in disease suppression and disappearance of patches.

We also continued to measure an increase in yield in SW following SB compared with continuous SW in the Ritzville long-term study, an observation first reported by Schillinger and Paulitz (31). Initially, we attributed this to the possibility that SB used less water than SW, leaving more water in the soil to increase subsequent SW yield. However, based on detailed soil water measurements (Fig. 4 ), we can state with certainty that the increase in grain yield of 


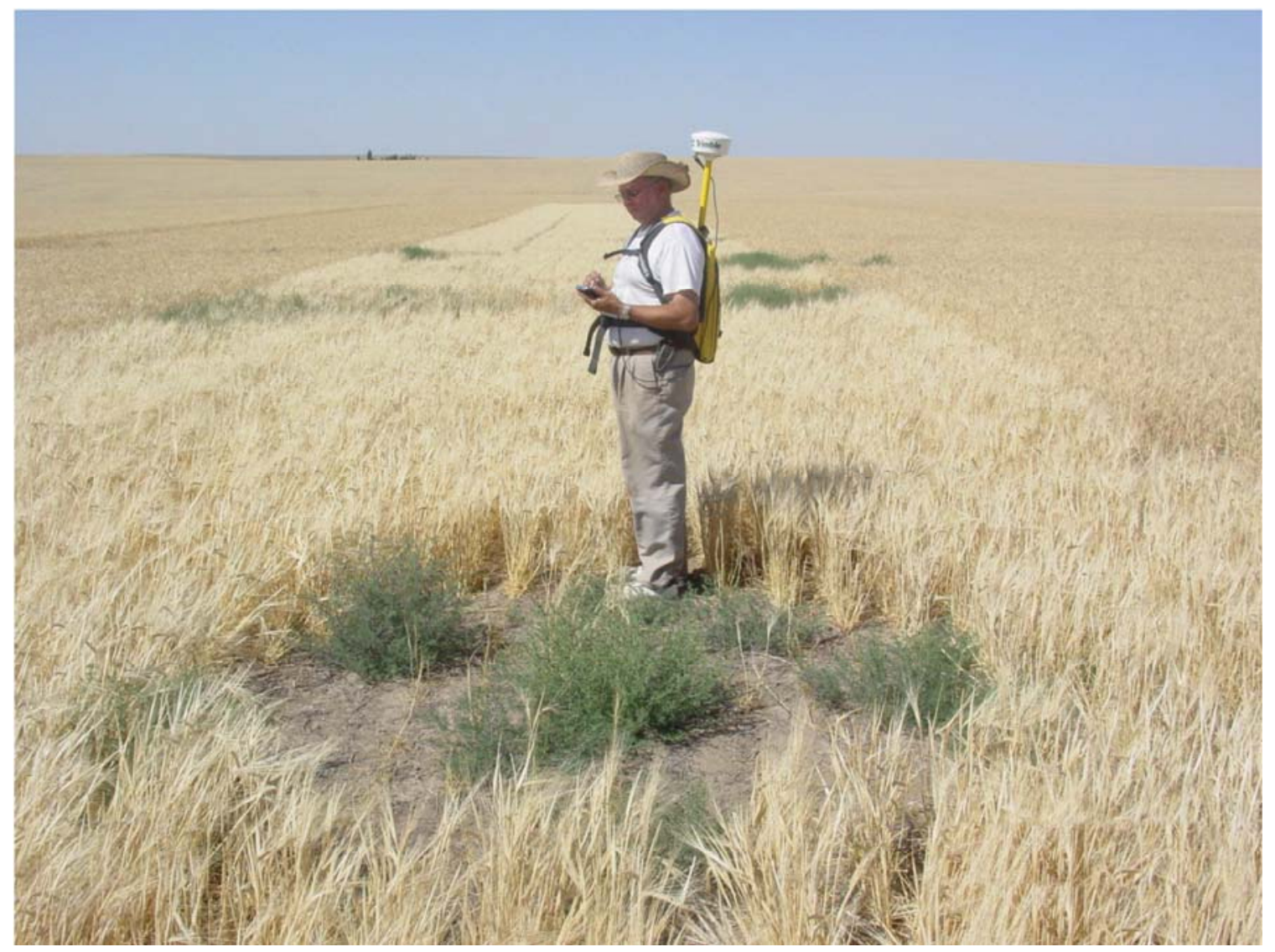

Fig. 5. Russian thistle, shown here in spring barley, was the only plant that grew in bare patches. Its taproot was able to penetrate through the layer of Rhizoctonia inoculum to access soil water present beneath patches. Cereal and oilseed crops grown in the large-scale experiment did not send roots underneath bare patches, thus leaving "islands" of stranded water.

SW after SB was not related to soil water content. We also hypothesized that a reduction in root lesion nematodes (Pratylenchus neglectus) may be responsible, because work by Smiley et al. (35) showed that barley is a poorer host than wheat. However, sampling at the Ritzville site in spring 2000 detected no root lesion nematodes in SW, SB, SAF, or YM (R. W. Smiley, personal communication, unpublished data) or at two other similar fields in Adams County, WA in SW, SB, or WW (36). It was also surprising because barley is a better host of $R$. solani than wheat, yet we saw less disease after barley. This phenomenon was also duplicated in the greenhouse, by growing successive crops of monocrop barley, and showing that the patches disappeared over the crop cycles (20). Based on this, we hypothesized that this barley rotation effect may have a microbial basis (31).

As previously reported from this site (31), water is stranded in bare patches. Soil water content within bare patches was uniform and significantly higher than in neighboring healthy SW, thus indicating that roots of affected crops will not grow into or underneath bare patch areas. Beginning in 2003, during the peak bare patch years, patches often became covered by Russian thistle (Fig. 5). Since its introduction to the PNW region in the early 1900s via a contaminated seed shipment, Russian thistle has been the most troublesome broadleaf weed in the low-precipitation region. This weed will germinate in repeated flushes in the spring and summer after rainfall events of $3 \mathrm{~mm}$ or more and quickly sends a taproot deep into the soil profile $(4,18)$. Russian thistle is a $\mathrm{C}_{4}$ plant with high water use. Once established, its tap root can grow below the inoculum level and access water in the patch. We pulled several well-established Russian thistle plants from within bare patches to confirm that roots were established in moist soil below the inoculum level.

This study demonstrates the value of long-term cropping systems studies to show that soilborne pathogens and disease are dy- namic over time, and may be suppressed by natural microflora. The next step is to definitively determine the microbial basis of this suppression. By understanding this, we can investigate cultural and rotation practices that may speed up the development of suppression. For example, does barley shift the bacterial populations to become more suppressive? If we can identify microbial markers that are predictive of the microbial communities responsible for suppression, this can speed up field research because these changes may be detectable before the disease starts to decline. Suppressive soils offer many advantages for disease management in a crop that has a relatively low economic value per unit area, such as dryland wheat. Suppression is sustainable because resistant cultivars (which have been elusive for breeders) and fungicide inputs are not required.

\section{Acknowledgments}

Funding for the research was provided by the United States Department of Agriculture NIFA through Special Grants to the Columbia Plateau PM10 Project and the Solutions to Environmental and Economic Problems Project. We thank R. Jirava, on whose farm this study was conducted; and Washington State University (WSU) Agricultural Research Technicians H. Schafer, T. Smith, and J. Jacobsen as well as WSU Technical Assistants S. Schofstoll and C. Warriner for their excellent support.

\section{Literature Cited}

1. Babiker, E. M., Hulbert, S. H., Schroeder, K. L., and Paulitz, T. C. 2011. Optimum timing of preplant applications of glyphosate to manage Rhizoctonia root rot in barley. Plant Dis. 95:304-310.

2. Baker, C. J., Saxton, K. E., and Ritchie, W. R. 1996. No-tillage Seeding: Science and Practice. CAB International, Wallingford, Oxon, UK.

3. Barnett, S. J., Roget, D. K., and Ryder, M. H. 2006. Suppression of Rhizoctonia solani Ag-8 induced disease on wheat by the interaction between Pantoea, Exiguobacterium, and Microbacteria. Aust. J. Soil Res. 44:331342.

4. Beckie, H. J., and Francis, A. 2009. The biology of Canadian weeds. 65 Salsola tragus L. (Updated). Can. J. Plant Sci. 89:775-789. 
5. Cook, R. J. 2007. Management of resident plant growth-promoting rhizobacteria with the cropping system: a review of experience in the US Pacific Northwest. Eur. J. Plant Pathol. 119:255-264.

6. Cook, R. J., Schillinger, W. F., and Christensen, N.W. 2002. Rhizoctonia root rot and take-all of wheat in diverse direct-seed spring cropping systems. Can. J. Plant Pathol. 24:349-358.

7. Dao, T. H. 1993. Tillage and winter wheat residue management effects on water infiltration and storage. Soil Sci. Soc. Am. J. 57:1586-1595.

8. Douglas, J. T., and Goss, M. J. 1982. Stability and organic matter content of surface soil aggregates under different methods of cultivation and in grassland. Soil Till. Res. 2:155-175.

9. Gupta, V. V. S. R., and Roget, D. K. 2007. Management of Rhizoctonia bare patch in southern Australian agricultural soils. CSIRO-GRDC Report. Australia.

10. Hignett, C., and Evett, S.R. 2002. Methods for measurement of soil water content: neutron thermalization. Pages 501-521 in: Methods of Soil Analysis. Part 4-Physical Methods. SSSA Book Series: 5. J. H. Dane and G. C. Topp, eds. Soil Science Society of America, Madison, WI.

11. Jaaffar, A. K. M. 2012. Isolation, identification, pathogenicity and sensitivity of Rhizoctonia spp. to phenazine-1-carboxylic acid (PCA)-producing Pseudomonas spp. Ph.D. diss. Washington State University, Pullman.

12. Large, E. C. 1954. Growth stages in cereals. Plant Pathol. 3:128-129.

13. Lucas, P., Smiley, R. W., and Collins, H. P. 1993. Decline of Rhizoctonia root rot on wheat in soils infested with Rhizoctonia solani AG-8. Phytopathology 83:260-265.

14. MacNish, G. C. 1988. Changes in take-all (Gaeumannomyces graminis var. tritici), Rhizoctonia root rot (Rhizoctonia solani) and soil $\mathrm{pH}$ in continuous wheat with annual applications of nitrogenous fertilizer in Western Australia. Aust. J. Exp. Agric.28:333-341.

15. MacNish, G. C., and Neate, S. M. 1996. Rhizoctonia bare patch of cereals An Australian perspective. Plant Dis. 80:965-997.

16. Miyan, M. S., Hüberli, D., and MacLeod. 2012. Identification of disease suppressive soils in Western Australia. In: Proc. 7th Aust. Soilborne Dis. Sympos.

17. Ophal-Keller, K., McKay, A., Hartley, D., Herdina, and Curran, J. 2008. Development of a routine DNA-based testing service for soilborne diseases in Australia. Australas. Plant Pathol. 37:243-253.

18. Pan, W. L., Young, F. L, and Bolton, R. P. 2001. Monitoring Russian thistle (Salsola iberica) root growth using a scanner-based, portable mesorhizotron. Weed Technol. 15:762-766.

19. Paulitz, T. C. 2006. Low input no-till cereal production in the Pacific Northwest of the US: the challenges of root diseases. Eur. J. Plant Pathol. 115:271-281

20. Paulitz, T. C., Schillinger, W. F., and Cook, R. J. 2003. Greenhouse studies of Rhizoctonia bare patch disease in soil cores from direct-seeded fields. CD-ROM. ASA, CSSA, and SSSA Abstracts in: American Society of Agronomy Annual Meeting, Denver.

21. Paulitz, T. C., and Schroeder, K. L. 2005. A new method for quantification of Rhizoctonia solani and R. oryzae from soil. Plant Dis. 89:767-772.

22. Paulitz, T. C., and Scott, R. 2005. Effect of seed treatments for control of Rhizoctonia root rot in winter wheat, 2003-2004. Plant Dis. Manage. Rep. 60: $\mathrm{CF} 028.22$

23. Paulitz, T. C., Smiley, R. W., and Cook, R. J. 2002. Insights into the prevalence and management of soilborne cereal pathogens under direct seeding in the Pacific Northwest, U.S.A. Can. J. Plant Pathol. 24:416-428.

24. Paulitz, T. C., and Steffenson, B. J. 2010. Biotic stress in barley: disease problems and solutions. In: Barley: Production, Improvement, and Uses. S. E. Ullrich, ed. Wiley-Blackwell, Oxford. Online publication. doi:10.1002/ 9780470958636.ch11

25. Paulitz, T. C., Yin, C., Hulbert, S., Schroeder, K., Schillinger, W., Marvrodi, O., Mavrodi, D., Kirkegaard, J., and Gupta, V. V. S. R. Role of microbial communities in the natural suppression of Rhizoctonia bare patch of wheat in the US and Australia. Page 13 in: Proc. 7th Australas. Soilborne Dis. Sympos. Freemantle, WA, Australia.

26. Pimentel, D., Harvey, C., Resosudarmo, P., Sinclair, K., Kurz, D., McNair, M., Crist, S., Shpritz, L., Fitton, L., Saufourri, R., and Blair, R. 1995. Environmental and economic costs of soil erosion and conservation benefits. Science 267:1117-1123.

27. Pumphrey, F. V., Wilkins, D. E., Hane, D. C., and Smiley, R. W. 1987. Influence of tillage and nitrogen fertilizer on Rhizoctonia root rot (bare patch) of winter wheat. Plant Dis. 71:125-127.

28. Roget, D. K. 1995. Decline in root rot (Rhizoctonia solani AG-8) in wheat in a tillage and rotation experiment at Avon, South Australia. Aust. J. Exp. Agric. 35:1009-1013.

29. Schalamuk, S., and Cabello, M. 2010. Arbuscular mycorrhizal fungal propagules from tillage and no-tillage systems: possible effects on Glomeromycota diversity. Mycologia 102:261-268.

30. Schillinger, W. F., Kennedy, A. C., and Young, D. L. 2007. Eight years of annual no-till cropping in Washington's winter wheat-summer fallow region. Agric. Ecosyst. Environ. 120:345-358.

31. Schillinger, W. F., and Paulitz, T. C. 2006. Reduction of Rhizoctonia bare patch in wheat with barley rotations. Plant Dis. 90:302-306.

32. Schroeder, K. L. 2004. The dynamics of root diseases of wheat and barley in the transition from conventional tillage to direct seeding. Ph.D. diss. Washington State University, Pullman.

33. Schroeder, K. L., and Paulitz, T. C. 2006. Root diseases of wheat and barley during the transition from conventional tillage to direct seeding. Plant Dis. 90:1247-1253.

34. Smiley, R. W., Backhouse, D., Lucas, P., and Paulitz, T. C. 2009. Diseases which challenge global wheat production-root, crown, and culm rots. In Wheat Science and Trade. B. F. Carver, ed. Wiley-Blackwell, Oxford. Online publication. doi:10.1002/9780813818832.ch6

35. Smiley, R. W., Machado, S., Gourlie, J. A., Pritchett, L. C., Yan, G. P., and Jacobsen, E. E. 2013. Effects of crop rotations and tillage on Pratylenchus spp. in the semiarid Pacific Northwest United States. Plant Dis. 97:537-546.

36. Smiley, R. W., Merrifield, K., Patterson, L., Whittaker, R. G., Gourlie, J. A. Easley, S. A. 2004. Nematodes in dryland field crops in the semiarid Pacific Northwest United States. Nematology 36:54-68.

37. Smiley, R. W., Wilkins, D. E., and Klepper, E. L. 1990. Impact of fungicide seed treatments on Rhizoctonia root rot, take-all, eyespot and growth of winter wheat. Plant Dis. 74:782-787.

38. Smith, J. D., Kidwell, K. K., Evans, M. A., Cook, R. J., Smiley, R. W. 2003. Evaluation of spring cereal grains and wild Triticum germplasm for resistance to Rhizoctonia solani AG-8. Crop Sci. 43:701-709.

39. Topp, G. C., and Ferre, P. A. 2002. Methods for measurement of soil water content: thermogravimetric using convective oven-drying. Pages 422-424 in: Methods of Soil Analysis. Part 4-Physical Methods. SSSA Book Series: 5. J. H. Dane and G. C. Topp, eds. Soil Science Society of America, Madison, WI

40. Weller, D. M., Cook, R. J., MacNish, G., Bassett, E. N., Powelson, R. L., and Petersen, R. R. 1986. Rhizoctonia root rot of small grains favored by reduced tillage in the Pacific Northwest. Plant Dis. 70:70-73.

41. Weller, D. M., Raaijmakers, J. M., McSpadden Gardener, B. B., and Thomashow, L. S. 2002. Microbial populations responsible for specific soil suppressiveness to plant pathogens. Annu. Rev. Phytopathol. 40:309-348.

42. Yin, C., Hulbert, S., Schroeder, K. L., Mavrodi, O., Mavrodi, D., Schillinger, W., and Paulitz, T. C. 2012. Natural suppression of Rhizoctonia roo rot by soil microbial communities in wheat from a Rhizoctonia decline site. Phytopathology 102:S4.141.

43. Yin, C., Hulbert, S. H., Schroeder, K. L., Mavrodi, O., Mavrodi, D., Dhingra, A., Schillinger, W. F., and Paulitz, T. C. 2013. The role of bacterial communities in the natural suppression of Rhizoctonia bare patch of wheat (Triticum aestivum L.) Appl. Environ. Microbiol. Online publication. doi:10.1128/AEM.01610-3 